\title{
Mantle processes during ocean formation: Petrologic records in peridotites from the Alpine- Apennine ophiolites
}

Dept. for the Study of the Territory and Resources, University of Genova, Corso Europa 26, 16132 Genova, Italy.

\begin{abstract}
Mantle peridotites were early exposed at the sea-floor of the Jurassic Tethys derived from the subcontinental mantle of the Europe-Adria system. During continental rifting and oceanic spreading, these lithospheric peridotites were percolated via diffuse reactive porous flow by melt fractions produced by near-fractional melting of the upwelling asthenosphere. Ascending melts interacted with the lower lithosphere, dissolving pyroxenes and precipitating olivine, and crystallized at shallower levels in the mantle column causing melt impregnation. Subsequent focused porous flow formed replacive dunite channels, cutting the impregnated peridotites, which were conduits for upward migration of MORB-type liquids. Melt migration produced depletion/refertilization and significant heating of the percolated/impregnated mantle, i.e the thermochemical erosion of the lithosphere. Impregnated and thermally modified lithospheric mantle was cooled by conductive heat loss during progressive lithosphere thinning and was intruded by MORB magmas, which formed Mg-rich and Fe-rich gabbroic dykes and bodies. Alpine-Apennine ophiolitic peridotites record the deep-seated migration of melts, which changed their compositions and dynamics during the rift evolution. The thermochemical erosion of the lithospheric mantle by the ascending asthenospheric melts, which induces significant compositional and rheological changes in the lower lithosphere, is a major process in the evolution of the continent-ocean transition towards a slow spreading oceanic system.
\end{abstract}

\section{Introduction}

Ophiolites exposed along the Western Alps-Northern Apennine orogenic chain represent the oceanic lithosphere of the Ligure-Piemontese (or Ligurian Tethys) basin which separated, during Late Jurassic- Cretaceous times, the Europe and Adria plates.

Since the early seventies (Bezzi and Piccardo, 1971; Decandia and Elter, 1972; Piccardo, 1976), it has been recognized that AlpineApennine ophiolites have anomalous pseudo-stratigraphy and lithological association, with respect to an idealised oceanic lithosphere formed at mature mid-ocean ridges (see reviews in: Rampone \& Piccardo, 2000; Piccardo et al., 2002). In fact: i) mantle peridotites are both fertile cpx-rich lherzolites, and depleted cpx-poor peridotites; ii) MORB-type gabbroic rocks are intruded into mantle peridotites; iii) mantle rocks record a decompressional subsolidus evolution, from lithospheric mantle depths to the sea-floor; iv) the serpentinized mantle peridotites are directly covered by MORB lava flows and radiolarian cherts, i.e. the first oceanic sediments.

The radiolarian cherts, which are frequently interlayered with the MORB lavas, show a Middle to Upper Jurassic age (De Wever and Caby, 1981; Marcucci and Passerini, 1991; Bill et al., 2001). Accordingly, a general agreement exists on the idea that the Ligurian Tethys was floored by a peridotite-gabbro basement, subsequently covered by discontinuous lava flows and oceanic sediments (Decandia and Elter, 1969; Piccardo, 1983; Lemoine et al., 1987), and on the assumption that the inception of the oceanic stage was not older than Upper Jurassic.

\section{Tectonic setting and opening mechanisms}

The Ligurian Tethys is believed to have developed by progressive divergence of the Europe and Adria blocks, in connection with the pre-Jurassic rifting and Late Jurassic opening of the Northern Atlantic (Dewey et al., 1973; Lemoine et al., 1987).

Paleotectonic reconstructions of the Ligurian Tethys suggest that the oceanic basin was not wider than 400-500 km (Stampfli, 1993) and that plate convergence led to complete closure of the Ligurian Tethys in the Early Tertiary, by means of an east-dipping subduction zone.

The peculiar stratigraphy of the Alpine-Apennine ophiolites led researchers to propose various genetic models: 1) the transform fault model (Gianelli and Principi 1977; Lemoine, 1980; Weissert and Bernoulli 1985), 2) the slow-spreading ridge model (Barrett and Spooner, 1977; Lagabrielle and Cannat, 1990; Lagabrielle and Lemoine, 1997), and 3) the low-angle detachment fault model (Lemoine et al. 1987; Froitzheim and Eberli 1990; Piccardo et al. 1990, 1994; Froitzheim and Manatschal 1996). The subcontinental origin of the mantle peridotites from the Ligurian ophiolites was stressed by some Authors (Decandia and Elter, 1969, 1972; Piccardo, 1976), which outlined the diversity of the Alpine-Apennine ophiolites compared with mature oceanic lithosphere formed at midocean ridges of modern oceans. Based on the atypical association of MORB magmatism and fertile subcontinental mantle, it was suggested (Piccardo, 1977; Beccaluva and Piccardo, 1978) that the Ligurian ophiolites were formed during early stages of opening of the oceanic basin, following rifting, thinning, and break-up of the continental crust, and were therefore located in a marginal, peri-continental position of the Jurassic oceanic basin. 


\section{The passive lithosphere extension}

The passive extension of the lithosphere has been recognized (Elter, 1972; Piccardo, 1976; Lemoine et al., 1987; Piccardo et al., $1990,1994)$ as the most suitable geodynamic process to account for the thinning and break-up of the Europe-Adria lithosphere and the opening of the Jurassic Ligurian Tethys. The passive extension caused (Piccardo et al., 1994): i) the tectonic exhumation and seafloor exposure of the sub-continental lithospheric mantle, and ii) the almost adiabatic upwelling of the asthenosphere, which underwent decompressional partial melting.

\section{Modern analogues}

The presence, in the Alpine-Apennine ophiolites, of a sub-continental peridotite basement and relics of stretched continental crust, which have been injected by MORB-type basaltic dykes, strongly recall the present setting in the embryonic ocean of the Northern Red Sea, i.e. the association of sub-continental peridotites and continental gneisses, cut by MORB basaltic dykes, which is exposed on the Zabargad Island (Bonatti et al., 1983; Piccardo et al., 1988, 1994). The origin of the Northern Red Sea has been related to the passive and asymmetric extension of the Nubian-Arabian lithosphere (Bohannon et al., 1989; Voggenreiter et al., 1988).

Moreover, the association of rifted sub-continental mantle and discontinuous MORB magmatism characterises the ocean-continent transition in the magma-poor rifted margin of Galicia (Western Iberia) (see: Manatschal and Bernoulli, 1999, and quoted references).

These settings represent, therefore, suitable modern analogues for the early evolution of the Jurassic Ligurian Tethys (Piccardo, 1995; Rampone and Piccardo, 2000). As early envisaged (Piccardo, 1977; Beccaluva and Piccardo, 1978), the formation of the AlpineApennine ophiolites must be inserted in a geodynamic scenario of passive rifting to incipient oceanisation in a slow spreading system (Vissers et al., 1991; Piccardo et al., 1994; Rampone and Piccardo, 2000). A similar interpretation has been proposed for the segments of the Jurassic Tethys margin exposed in the Malenco and Platta-Err nappes of the Central Alps (Manatschal and Bernoulli, 1999; Müntener and Hermann, 2001; Schaltegger et al., 2002).

\section{Main features of the Tethyan ophiolites}

\section{Basaltic volcanites}

Petrologic and geochemical studies have provided clear evidence of the overall tholeiitic composition and MORB affinity of the basaltic volcanites, ranging from T-MORB to N-MORB (Piccardo et al., 2002, and quoted references). Geochemical modelling indicates that the most primitive T-MORB and N-MORB-type basalts are consistent with melts generated by variable degrees of fractional melting of a MORB-type asthenospheric mantle source (Vannucci et al., 1993). These basalts have fairly homogeneous $\mathrm{Nd}$ isotopic ratios, consistent with their MORB affinity (Rampone et al., 1998).

\section{Gabbroic intrusives}

The dominant intrusive rock types are (Serri, 1980; Hebert et al., 1989; Piccardo, 1995; Tribuzio et al., 2000): i) ultramafic cumulates (pl-cpx-bearing cumulus dunites); ii) Mg-Al-gabbros (troctolites, olgabbros and cpx-gabbros); iii) Fe-Ti-gabbros (Fe-Ti-oxide-bearing gabbros and diorites); iv) plagiogranites (diorites and throndhjemites). They show the crystallization sequence [olivine(ol) Æplagioclase(plg)Æclinopyroxene(cpx)] and covariations of Fo in ol, An in plg and Mg-number in cpx, which are typical of low pressure crystallization of olivine tholeiites. Clinopyroxenes of primitive ol-cumulates and ol-gabbros have rather flat HREE to MREE patterns, at about $9-10 \times \mathrm{C} 1$, and significant LREE depletion $\left(\mathrm{Ce}_{\mathrm{N}} / \mathrm{Sm}_{\mathrm{N}}=\right.$ $0.21-0.29)$. Simple geochemical modelling indicates a MORB affin- ity for the primary liquids, in agreement with the $\mathrm{Sr}$ and $\mathrm{Nd}$ isotope ratios of ol-gabbros and their clinopyroxenes (Rampone et al., 1998).

\section{Mantle peridotites}

Most peridotites from the Alpine-Apennine ophiolites (LanzoLiguria-Corsica) are spinel-facies lherzolites: they are characterized by relict protogranular textures, $\mathrm{km}$-scale tectonite-mylonite shear zones, presence and enrichment of plagioclase, spinel dunite bodies and channels, and late $\mathrm{Mg}$-rich to $\mathrm{Fe}-\mathrm{Ti}$-rich gabbroic dykes and bodies.

Spinel peridotites vary in composition from rather fertile (i.e. External Liguride peridotites) to variably depleted [i.e. Erro-Tobbio (Voltri Massif), Internal Liguride, Monte Maggiore (Corsica), and Lanzo peridotites]. They show a complete equilibrium metamorphic recrystallisation, attained under spinel-facies conditions at $\mathrm{T}=$ 900-1100 ${ }^{\circ} \mathrm{C}$ (Piccardo, 1976; Rampone et al., 1993, 1995). This event documents the accretion of their asthenospheric protoliths to the thermal lithosphere, and their annealing recrystallization along a conductive geotherm (Piccardo et al., 1994). Available Sm-Nd DM model ages suggest that the Ligurian peridotites were isolated from the convecting asthenosphere, and were accreted to the thermal lithosphere, during Proterozoic times (the External Liguride fertile lherzolites: Rampone et al., 1995), pre-Carboniferous times (the Erro-Tobbio depleted peridotites: Piccardo et al., 2002), Permian times (the Internal Liguride depleted peridotites: Rampone et al., 1996). The Southern Body of the Lanzo Massif has been interpreted as an asthenosphere diapir that rose from the garnet stability field and was emplaced in early Mesozoic, during the opening stages of the Ligure-Piemontese basin, whereas the Northern Body has been considered a fragment of the sub-continental lithosphere which became isolated by the convecting mantle 400-700 Ma ago (Bodinier et al., 1991, and the quoted references). $\mathrm{Sm} / \mathrm{Nd}$ isotope data on the Monte Maggiore peridotites furnish Jurassic (165 Ma) DM model age of depletion (Rampone, 2002).

Most of these ophiolitic peridotite massifs show large areas where plagioclase is present and, frequently, rather abundant. Plagioclase formation in mantle peridotites have been differently interpreted, as deriving from: i) metamorphic recrystallisation, ii) low pressure partial melting, or iii) melt impregnation. The presence of plagioclase in the Alpine-Apennine ophiolitic peridotites has been related to: 1) incomplete melt extraction and crystallisation after low pressure partial melting (Lanzo: Boudier and Nicolas, 1972; Boudier, 1978; Nicolas, 1986); 2) subsolidus recrystallisation (External Ligurides: Piccardo, 1976; Rampone et al., 1993, 1995); 3) exotic melt percolation and impregnation (Monte Maggiore and Internal Ligurides: Rampone et al., 1997). Recent studies on AlpineApennine peridotites (Piccardo et al., 2002; Müntener and Piccardo, 2003) suggest that:

1) The presence of reduced amounts of plagioclase, confined to plg+ol reaction rims between spinel and pyroxenes and to plg+olrich granoblastic aggregates between spinel-facies minerals, documents the metamorphic transition from spinel- to plagioclasefacies conditions, according to the reaction: spinel+pyroxenes $Æ$ olivine+plagioclase;

2) The presence of significant amounts of plagioclase, diffuse in the rock as both unstrained crystals and plg+opx $(+\mathrm{cpx})$-rich granular aggregates interstitial between the deformed mantle minerals, documents the interstitial crystallisation of exotic melts, which impregnated previous spinel peridotites.

\section{Mantle processes during ocean opening}

Ophiolitic mantle peridotites from the Jurassic Ligure-Piemontese basin show field, petrologic and geochemical features which reveal the processes they underwent after their accretion to the lithosphere and before their sea-floor exposure. The following sequence of mantle processes can been recognised and related to the rifting stage of the Ligure-Piemontese basin (see also: Piccardo et al., 2002; Müntener and Piccardo, 2003). 


\section{1) Decompressional evolution of the lithospheric mantle}

The passive extension of the Europe-Adria lithosphere and the inception of rifting in the Ligure-Piemontese basin were recorded in the lithospheric mantle by development of extensional shear zones, leading to gradual upwelling of segments of the lithospheric mantle, and by incipient to extensive recrystallisation under decompression to plagioclase- and amphibole-facies conditions. Geothermometric estimates indicated that the temperature conditions were slightly to significantly decreasing during the decompressional evolution (Piccardo, 1976; Hoorgeduijn Strating et al., 1993; Rampone et al., 1993,1995).

\section{2) Melt percolation and impregnation}

Extension and thinning of the lithosphere was accompanied by almost adiabatic upwelling of the underlying asthenosphere, which underwent partial melting under decompression.

\section{Melt percolation by porous flow and melt interstitial crystallisation}

Melts formed in the asthenosphere migrated through the overlying lithospheric mantle column via porous flow (Piccardo et al., 2002; Müntener and Piccardo, 2003). Melt/peridotite interaction (i.e. olivine precipitation and pyroxenes dissolution) most probably transformed the percolated lherzolites to cpx-poor peridotites, forming a lower zone of "reactive" harzburgites (Xu et al., 2003) at the expense of the percolated lithospheric mantle. At shallower levels in the lithospheric mantle column, the percolating melts began to crystallise, when cooling down to their liquidus temperatures. Melt crystallisation produced $\mathrm{mm}$-scale veins and interstitial granular aggregates of undeformed magmatic minerals between the deformed porphyroclastic mantle minerals and caused pervasive impregnation of the lithospheric mantle. At the impregnation level, melts either: 1) reacted with and partially replaced the mantle clinopyroxenes, forming opx+plg symplectites, and crystallised opx-rich, cpx-free noritic microgranular aggregates (Internal Liguride and Monte Maggiore peridotites: Rampone et al., 1997; Piccardo et al., 2002), or 2) did not react with the mantle clinopyroxenes and crystallised opx-rich, cpxbearing gabbro-noritic microgranular aggregates (Lanzo peridotites: Piccardo et al., 2002; Müntener and Piccardo, 2003).

Regarding the chemistry and origin of the trapped melts in the Monte Maggiore impregnated peridotites, Rampone et al. (1997) suggested that they probably consisted of unmixed depleted melt increment produced by 6-7\% fractional melting on an asthenospheric mantle source.

Early crystallisation and abundance of orthopyroxene in the interstitial magmatic aggregates, and orthopyroxene replacement on mantle olivine, indicates that the impregnating melts were silica- and opx-saturated (as in the Internal Liguride and Monte Maggiore peridotites), whereas the interstitial crystallisation of clinopyroxene evidences that melts attained cpx-saturation (as in the Lanzo peridotites). The pyroxenes-saturation of the impregnating melts supports the idea that they migrated upward by reactive porous flow (Piccardo et al., 2002) and reacted with the country peridotite, dissolving mantle pyroxenes and crystallising olivine, as proposed by Kelemen et al. (1995).

Porphyroclastic mantle pyroxenes in the impregnated peridotites from Monte Maggiore, Lanzo and Internal Ligurides have unusual trace element compositions, significantly enriched in many trace elements (i.e. REE, Ti, Sc, V, Zr, Y), with respect to porphyroclastic pyroxenes in the spinel lherzolites from the same peridotite body and to clinopyroxenes in equilibrium with MORB melts. Enriched clinopyroxenes show convex-upward REE patterns with a significant REE enrichment (MREE up to $30 \times \mathrm{C} 1$ in some Lanzo samples), and both ortho- and clinopyroxenes frequently show a negative Eu $\mathrm{N}_{\mathrm{N}}$ anomaly (Figure 1). At Lanzo, clinopyroxenes in the same sample, as both mantle porphyroclasts and interstitial mag- matic grains, show remarkably similar trace element compositions. Mantle and magmatic orthopyroxenes follow the same trend as clinopyroxenes. These features suggest that; 1) mantle and magmatic pyroxenes attained trace element equilibrium with the percolating melts, 2) the percolating melts changed their major/trace element composition via melt/rock reaction (olivine crystallisation and pyroxenes dissolution) during reactive porous flow in the mantle column.

At Lanzo, the trace element budgets of magmatic pyroxenes and plagioclases in the gabbroic microgranular aggregates of the impregnated peridotites vary from sample to sample. In fact, clinopyroxenes show a negative LREE fractionation which changes from slight to strong $\left(\mathrm{La}_{N} / \mathrm{Sm}_{\mathrm{N}}=\right.$ from 0.19 to 0.01$)$ : this variation is accompanied by a progressive change, from positive to negative, of the plagioclase LREE fractionation $\left(\mathrm{La}_{N} / \mathrm{Sm}_{\mathrm{N}}=\right.$ from 3.60 to 0.10 ; $\mathrm{La}_{\mathrm{N}} / \mathrm{Pr}_{\mathrm{N}}=$ from 1.20 to 0.07 ). Plagioclase shows a parallel decrease in the $\mathrm{Sr}$ (from 154 to $5.7 \mathrm{ppm}$ ) and $\mathrm{Na}$ (from An67\% to An87\%) contents. The above compositional variations of the main magmatic minerals of the impregnated peridotites is, most probably, related to the progressive change in the composition of the primary melts, from slightly Sr-LREE enriched to significantly depleted, due to the progressive increase in the melting degrees during near-fractional melting of the upwelling asthenospheric mantle.

Melt impregnation produced the chemical refertilization of the lithospheric mantle, i.e. addition of basaltic components (the gabbroic microgranular aggregates) and significant trace element enrichment of the mantle minerals, when attaining geochemical equilibrium with the compositionally modified, impregnating melts. Thermometric estimates based on trace element (i.e. Sc and V) distribution between coexisting pyroxenes (Seitz et al., 1999) of the impregnated peridotites, indicate that magmatic aggregates and mantle porphyroclasts records the same equilibrium temperatures (about $1250-1300{ }^{\circ} \mathrm{C}$ ) (Piccardo et al., 2002; Müntener \& Piccardo, 2003). This fact is in favour of a significant heating of the lithospheric mantle during melt percolation and impregnation. The high temperatures favoured attainment of the trace element equilibrium between melts and mantle minerals. In conclusion, the lithospheric mantle was subjected to significant thermochemical erosion (chemical refertilization plus heating) during the asthenosphere/ lithosphere interaction which accompanied the rifting stage of the basin (Piccardo et al., 2002; Müntener and Piccardo, 2003).

\section{Melt percolation by focussed porous flow}

Field evidence at Lanzo and Monte Maggiore indicates that the impregnated peridotites are locally cut and replaced by bodies and channels of spinel dunites (Boudier and Nicolas, 1972, Boudier, 1978; Piccardo et al., 2002; Müntener and Piccardo, 2003). This suggests that, after impregnation, the melt infiltration processes in the lithospheric mantle were focused in the dunite channels and the migration mechanisms changed from diffuse to channelled porous flow.

The melts migrating in dunite channels crystallized, small interstitial clinopyroxenes, at olivine triple points, plagioclase+clinopyroxene films surrounding olivine crystals and gabbroic veinlets with fuzzy contacts. At Lanzo, clinopyroxenes in dunites have almost flat M- HREE patterns (at <10 $\times \mathrm{C} 1)$ and moderate LREE depletion, without any trace element enrichment. Geochemical modelling indicates that melts percolating in dunites were significantly different from the melts which produced impregnation in spinel peridotites. They were primary liquids similar to MORB (Piccardo et al., 2002; Müntener and Piccardo, 2003), which remain unmodified during upwelling and escaped melt/peridotite reaction. This is consistent with the idea that melts migrating in dunite channels may be not affected by melt/rock reaction and that focused flow in restricted conduits is required for MORB extraction from the mantle (Kelemen et al., 1995, 1997). 


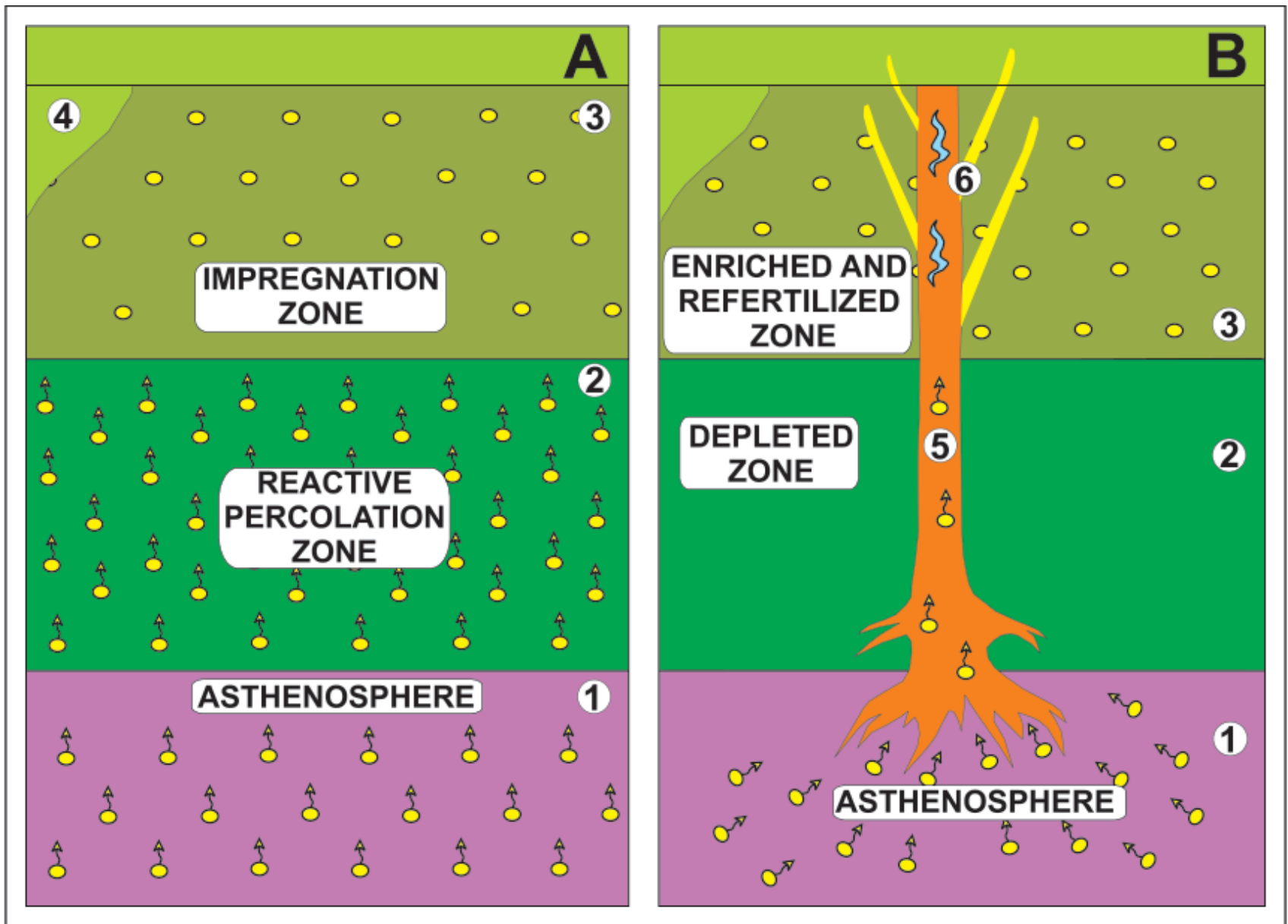

Figure 1 Asthenosphere/lithosphere interaction via upward migration of hot asthenospheric melts, as evidenced by field, petrologic and geochemical data from the Lanzo peridotite massif.

(A) Decompressional melting in the rising asthenosphere (1) produced variably enriched/depleted melts, most probably consisting of single melt fractions after fractional melting processes. These single melt increments migrated isolatedly through the overlying mantle

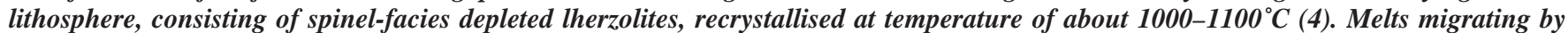
reactive porous flow heated the lower lithosphere to $1250-1300^{\circ} \mathrm{C}$ and interacted with the peridotites (dissolving pyroxenes and crystallising olivine) (2): migrating melts attained pyroxenes- and silica-saturation and were, most probably, enriched in most trace elements, whereas lithospheric peridotites were transformed to reactive harburgites. At shallower levels (3), where the competing effects between heating by melt percolation and cooling by conductive heat loss caused interstitial melt crystallisation within the percolated mantle, spinel peridotites were strongly impregnated and refertilized, by addition of basaltic components (i.e. interstial micro-granular gabbroic aggregates) and by trace element enrichment of mantle minerals, when attaining trace element equilibrium with the impregnating melts.

(B) Following the early asthenosphere/lithosphere interaction by melt percolation, which formed a lower section of reactive harzburgites (depleted zone) and an upper section of impregnated peridotites (enriched and refertilized zone), the single melt fractions were, most probably, aggregated in the asthenosphere to form MORB-type aggregated melts, which migrated upward via focused porous flow within dunite channels (5). The dunite channels acted as preferential ways for upwards migration of melts: when cooling down to their liquidus temperatures, the migrating melts crystallised clinopyroxene+plagioclase, interstitial to the large olivine crystals. In places, clinopyroxene and plagioclase form gabbroic patches, veinlets and dykelets (6), which intrude, with fuzzy contacts, the surrounding impregnated peridotites. These features suggest that the interstitial crystallisation in the dunite channels caused progressive clogging of the melt migration ways and forced the migrating melts to intrude along cracks and fractures.

\section{3) Early veining and dyking of gabbroic material}

The dunite channels acted as preferential ways for upwards migration of melts: when cooling down to their liquidus temperatures, the migrating melts crystallised interstitial plagioclase+ clinopyroxene, gabbroic veinlets and dykelets, which intrude the surrounding impregnated peridotites, showing fuzzy contacts. These features suggest that the interstitial crystallisation in the dunite channels caused progressive clogging of the melt migration ways and forced the migrating melts to intrude along cracks and fractures.

Accordingly, following diffuse reactive porous flow, pervasive melt impregnation and focused flow in dunite channels, the melt migration mechanisms changed from diffuse/focused percolation to intrusion. At Lanzo, cm-scale gabbroic veins and dykelets were intruded in the impregnated peridotites, at Monte Maggiore, the early intrusion produced $\mathrm{m}$-scale cumulate pods and $\mathrm{cm}$-scale gabbroic dykelets. The gabbroic veins and dykelets in both peridotite massifs, and the cumulate pods at Monte Maggiore, have Mg-rich olivine (Fo90) and pyroxenes (Mg\#90-92): they were formed, accordingly, by early crystallisation of rather primitive melts. These magmatic pyroxenes, differently to the magmatic pyroxenes of the previous impregnation, don't show any trace element enrichment, indicating that the intruding melts escaped significant melt/rock reaction during upwelling. The gabbroic dykelets at Lanzo South 


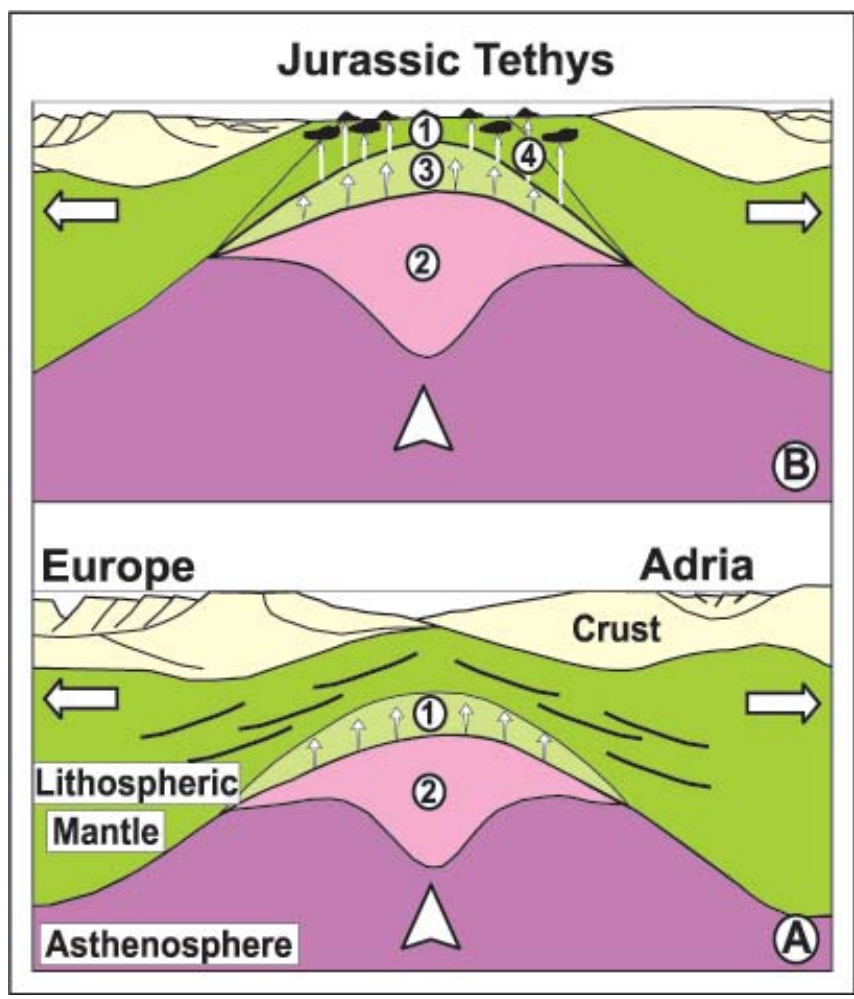

Figure 2 Jurassic rifting and drifting stages of the Ligurian Tethys. (A) Continental rifting: early percolation and impregnation of the pre-Jurassic subcontinental mantle lithosphere (Lanzo-type) (1) by ascending hot melts which are formed in the upwelling molten asthenosphere (2);

(B) Oceanic drifting: percolation and impregnation of Jurassic oceanic mantle lithosphere (M. Maggiore-type) (3), intrusion and extrusion of MORB-type magmas (4) (not to scale). The modified mantle lithosphere [(1) and (3)] most probably consists of $i$ ) a lower section of reactive harburgites, and of ii) an upper section of impregnated and refertilized peridotites.

have plagioclases with relatively high $\mathrm{Na}$ (An54-66\%) and very high Sr (500-750 ppm) contents, whereas cumulates and dykelets at Monte Maggiore have Ca-rich (An88-96\%), and extremely Sr-poor (20-30 ppm) plagioclases. Clinopyroxenes have almost flat REE patterns in the M-HREE region (at $<10 \times \mathrm{C} 1$ ), but significantly different LREE negative fractionation and incompatible trace element contents. Geochemical modelling indicates that: i) the primary melts of the Lanzo dykelets most probably correspond to low degrees (2-3\%), melt increments, or low degrees aggregated melts, after near-fractional melting of an asthenospheric mantle source, ii) the primary melts of the Monte Maggiore dykelets and cumulates correspond to higher degrees (6-7\%), strongly depleted melt increments, or higher degrees depleted aggregated melts, after near-fractional melting.

Above evidence suggests that the earliest melts which percolated and impregnated the ophiolitic peridotites were, most probably, single melt increments which escaped aggregation and survived unmixed during ascent; they migrated through the lithospheric mantle column by reactive porous flow, attaining pyroxene(s) saturation. Subsequent focused percolation in dunite channels and intrusion along fractures allowed both depleted melt fractions (Monte Maggiore) and MORB-type melts (Lanzo) to ascend in the lithospheric mantle without significant melt/peridotite reaction.

\section{4) Intrusion of gabbroic dykes and bodies}

The Alpine-Apennine ophiolitic peridotites are intruded by meter-wide gabbroic dykes and km-scale gabbroic bodies, showing sharp contacts and chilled margins to the country peridotite and cut- ting across all previous mantle and magmatic structures. They vary in composition from rather primitive troctolite to $\mathrm{Mg}$-gabbros to $\mathrm{Fe}$ Ti-gabbros, and rare plagiogranites. Computed liquids in equilibrium with clinopyroxenes from the most primitive olivine gabbros are closely similar to average aggregated MORBs. MORB-type evolved magmas were intruded when the lithospheric mantle was cold and brittle, at shallow levels in the conductive lithosphere.

\section{Discussion and conclusion}

Present knowledge on the Alpine-Apennine ophiolitic peridotites allow to constrain some major steps in the formation of the Jurassic Ligurian Tethys ocean, and to outline the mantle processes which accompanied the geodynamic evolution during rifting and opening of the basin.

After partial melting and accretion to the thermal lithosphere, the mantle sections of the Alpine-Apennine ophiolites were exhumed towards the sea-floor during passive extension of the Europe-Adria lithosphere. During lithosphere thinning, the underlying asthenosphere rose up and underwent near-adiabatic decompression melting: the resulting fractional melts migrated through and reacted with the overlying mantle lithosphere.

Alpine-Apennine ophiolitic peridotites record distinct magmatic cycles: (1) the diffuse porous flow and impregnation of depleted/enriched isolated fractional melt increments, which underwent pyroxenes-saturation and modification of the major/trace element composition by melt/rock reaction during upwelling, (2) the focused percolation in dunite channels and the early intrusion of depleted/enriched melt fractions and MORB-type primary melts, and (3) the late intrusion of variably fractionated magmas deriving from aggregated MORB melts.

\section{Chemical depletion/refertilization and thermal erosion of the lithosphere}

The chemical and rheological relevance of the enrichment processes in the lithospheric mantle peridotites has been stressed by Menzies and co-workers (1987). The combination of lithosphere extension in a rifting system and the intrusion of magmas from the upwelling asthenosphere have been considered as important factors which may accomplish the thermomechanical erosion of the lithosphere (Davies, 1994). Evidence of km-scale porous melt flow in the Ronda peridotites, related to pervasive infiltration of asthenospheric melts, has been regarded as a volumetrically important process accompanying the thermomechanical erosion of the lower lithosphere by the upwelling asthenosphere (Van der Wall and Bodinier, 1996). Infiltration of asthenospheric magmas in the lower lithosphere has been considered a peculiar feature of the early stages of continental rifting in eastern Africa (Bedini et al., 1997). The "reactive" formation of harburgites via melt percolation, as a consequence of lithosphere-asthenosphere interaction during lithospheric thinning, has been recently documented by Xu et al. (2003).

The outlined features of the Alpine-Apennine ophiolitic peridotites evidence that significant asthenosphere/lithosphere interaction followed the rifting stages of the Ligurian Tethys: the upward migration of hot asthenospheric melts caused significant chemical modifications (depletion/refertilization) and thermal erosion of the lithospheric mantle. Melt/peridotite reaction formed a lower zone of depleted reactive harzburgites or cpx-poor lherzolites at the base of the lithospheric mantle column. During melt upward migration, the competing effects of heating by melt percolation and cooling by ongoing exhumation caused the interstitial crystallisation of early liquidus phases in the percolated lithospheric mantle and the progressive clogging of the melt channels. This formed an upper zone of refertilized, impregnated lherzolites.

The thermochemical erosion of the lower lithospheric mantle was a fundamental step in the evolution of the Ligure-Piemontese basin. The thermal softening of the extending lithosphere could have 
played an important role in the dynamics of the rifting system during transition from passive lithosphere extension to active oceanic drifting in a slow spreading system.

\section{Melt dynamics and mantle rheology}

The change of the melt migration mechanisms from pervasive to focused porous flow and finally dyking suggests that the rheology of the lithospheric mantle was modified by the lithosphere/asthenosphere interaction during lithosphere extension and thinning. The relatively cold peridotites of the lithospheric mantle column attained more hot and plastic, asthenospheric characteristics, when they underwent thermochemical erosion during melt percolation.

Diffuse melt crystallisation under progressive cooling stopped porous flow and enhanced melt focusing into cracks and fractures. During ongoing upwelling in the thermal lithosphere, the thermochemically modified lithospheric mantle went back to more cold and brittle conditions, when it was subjected to increasing conductive heat loss. This is well consistent with the progressive thinning of the Europe-Adria lithosphere during the extension which governed the rifting stage of the Ligure-Piemontese basin.

The variations in rheology of the lithospheric mantle during rifting was accompanied by changes in the melt dynamics in the asthenosphere. During the early melting stages of the upwelling asthenosphere, single melt increments produced by fractional melting escaped aggregation, survived unmixedly and migrated isolatedly. Subsequently, the melt fractions were more efficiently mixed and completely aggregated to form MORB magmas. These aggregated MORBs underwent differentiation, most probably, within small magma chambers: variably fractionated magmas were formed and intruded as $\mathrm{Mg}$ - to Fe-Ti-rich gabbroic dykes with MORB affinity and, later, were extruded as variably evolved MORB-type lava flows.

\section{Acknowledgements}

The Italian MURST and the University of Genova are acknowledged for financial supports. An early draft of the manuscript has benefited from the constructive criticism of $\mathrm{O}$. Müntener, G. Ranalli, A. Zanetti. Thanks are due to S. Bruzzone, E. Poggi, A. Romairone, G. Spagnolo for field work, data production and elaboration.

\section{References}

Anders, E., and Ebihara, M., 1982, Solar system abundances of the elements. Geochim. Cosmochim. Acta, v. 46, pp. 2363-2380.

Barrett, J.J., and Spooner, E.F.C., 1977, Ophiolitic breccias associated with allochtonous oceanic crustal rocks in the East Ligurian Apennines, Italy A comparison with observations from rifted oceanic ridges. Earth Planet. Sci. Lett., v. 35, pp. 79-91.

Beccaluva, L., Macciotta, G., Piccardo, G.B., and Zeda, O., 1984, Petrology of lherzolitic rocks from the Northern Apennine ophiolites. Lithos, v. 17, pp. 299-316.

Beccaluva, L., and Piccardo, G.B., 1978, Petrology of the Northern Apennine ophiolites and their significance in the Western Mediterranean area, in Closs H., Roeder D. and Schmidt K., eds, Alps, Apennines, Hellenides, Inter-Union Commission on Geodynamics, Scientific Report n. 38, E. Schweizerbart'sche Verlagsbuchhandlung, Stuttgart, pp. 243-254.

Bedini, R.M., Bodinier, J.-L., Dautria, J.-M., and Morten, L., 1997, Evolution of LILE-enriched small melt fraction in the lithospheric mantle: a case study from the East African Rift. Earth Planet. Sci. Lett., v. 153, pp. 6783.

Bezzi, A., and Piccardo, G.B., 1971, Structural features of the Ligurian ophiolites: petrologic evidence for the "oceanic" floor of Northern Apennines geosyncline. Mem. Soc. Geol. It., v. 10, pp. 53-63.

Bill, M., O'Dogherty, L., Guex, J., Baumgartner, P.O., and Masson, H., 2001, Radiolarite ages in Alpine-Mediterranean ophiolites: Constraints on the oceanic spreading and the Tethys-Atlantic connection. Geol. Soc. Am. Bull., v. 113, pp. 129-143.
Bodinier, J.-L., Menzies, M.A., and Thirlwall, M.F., 1991, Continental to oceanic mantle transition - REE and Sr-Nd isotopic geochemistry of the Lanzo lherzolite massif. J. Petrol., Special Lherzolite Issue, pp. 191-210.

Boudier, F., and Nicolas, A., 1972, Fusion partielle gabbroïque dans la lherzolite de Lanzo (Alpes piémontaises). Schweizerische Mineralogische und Petrographische Mitteilungen, v. 52, pp. 39-56.

Boudier, F., 1978, Structure and petrology of the Lanzo peridotite massif (Piedmont Alps). Geological Society of America Bulletin, v. 89, pp. 1574-1591.

Davies, G.F., 1994, Thermomechanical erosion of the lithosphere by mantle plumes. J. Geophys. Res, v. 99, pp. 15,709-15,722.

Decandia, F.A., and Elter, P., 1969, Riflessioni sul problema delle ofioliti nell'Appennino Settentrionale (Nota preliminare). Atti della Societá Toscana di Scienze Naturali, v. 75, pp. 1-9.

Decandia, F.A., and Elter, P., 1972, La zona ofiolitifera del Bracco nel settore compreso fra Levanto e la Val Graveglia (Appennino Ligure). Mem. Soc. Geol. It., v. 11, pp. 503-530.

Dewey, J.F., Pittman III, W.C., Ryan, W.B.F., and Bonnin, J., 1973, Plate Tectonics and the evolution of the alpine system. Geol. Soc. America Bull., v. 84, pp. 3137-3180.

De Wever, P., and Caby, R., 1981, Datation de la base des Schistes Lustrés post-ophiolitiques par des radiolaires (Oxfordien Supérieur-Kimmeridgien Moyen) dans les Alpes Cottiennes (Saint-Veran, France). Comptes Rendus de l'Académie des Sciences, Paris, v. 292, pp. 467-472.

Elter, P., 1972, La zona ofiolitica del Bracco nel quadro dell'Appennino Settentrionale. Introduzione alla geologia delle Liguridi. $66^{\circ}$ Congresso della Società Geologica Italiana, Guida alle Escursioni, Pacini, Pisa, pp. 5-35.

Froitzheim, N. \& Eberli, G.P. 1990, Extensional detachment faulting in the evolution of a Tethys passive continental margin, Eastern Alps, Switzerland. Geological Society of America Bulletin, v. 102, pp. 1297-1308.

Froitzheim, N. \& Manatschal, G. 1996, Kinematics of Jurassic rifting, mantle exhumation, and passive-margin formation in the Austroalpine and Penninic nappes (eastern Switzerland). Geological Society of America Bulletin v.108, pp. 1120-1133.

Hebert, R., Serri, G., and Hekinian, R., 1989, Mineral chemistry of ultramafic tectonites and ultramafic to gabbroic cumulates from the major oceanic basins and Northern Apennine ophiolites (Italy) - A comparison. Chemical Geology, v. 77, pp. 183-207.

Hoogerduijn Strating, E.H., Rampone, E., Piccardo, G.B., Drury, M.R., and Vissers, R.L.M., 1993, Subsolidus emplacement of mantle peridotites during incipient oceanic rifting and opening of the Mesozoic Tethys (Voltri Massif, NW Italy). J. Petrol., v. 34, pp. 901-927.

Kelemen, P.B., Whitehead, J.A., Aharonov, E., and Jordahl, K.A., 1995 Experiments on flow focusing in soluble porous media, with applications to melt extraction from the mantle. J. Geophys. Res., v. 100, pp. 475-496.

Kelemen, P.B., Hirth, G., Shimizu, N., Spiegelman, M., and Dick, H.J.B. 1997, A review of melt migration processes in the adiabatically upwelling mantle beneath oceanic spreading rideges. Phil. Trans. R. Soc. London, v. 355, pp.283-318.

Lagabrielle, Y., and Cannat, M., 1990, Alpine Jurassic ophiolites resemble the modern Central Atlantic basement. Geology, v. 18: pp. 319-322.

Lemoine, M., Tricart, P., and Boillot, G., 1987, Ultramafic and gabbroic ocean floor of the Ligurian Tethys (Alps, Corsica, Apennines): in search of a genetic model. Geology, v. 15, pp. 622-625.

Manatschal, G., and Bernoulli, D., 1999, Architecture and tectonic evolution of non-volcanic margins: present-day Galicia and ancient Adria. Tectonics, v. 18, pp. 1099-1119.

Marcucci, M., and Passerini, P., 1991, Radiolarian-bearing siliceous sediments in the Mesozoic of the Northern and Central Apennines. Ofioliti, v. 16 , pp. $121-126$

Marroni, M., Molli, G., Montanini, A., and Tribuzio, R., 1998, The association of continental crust rocks with ophiolites in the Northern Apennines (Italy): implications for the continent-ocean transition in the Western Tethys. Tectonophysics, v. 292, pp. 43-66.

Menzies, M.A., Rogers, N., Tidle, A., Hawkesworth, C.J., 1987, Metasomatism and enrichment processes in lithospheric peridotites, an effect of asthenosphere-lithosphere interaction, in M. Menzies; C.J. Hawkesworth, eds, Mantle metasomatism, Academic Press, London, pp. 313-361.

Müntener, O., and Hermann, J., 2001, The role of lower crust and continental upper mantle during formation of non volcanic passive continental margins: evidences from the Alps. Geol. Soc. London, Special Publ. V. 187 , pp. $267-288$

Müntener, O., and Piccardo, G.B., 2003, Melt migration in ophiolitic peridotites: the message from Alpine-Apennine peridotites and implications for embryonic ocean basins. Geological Society of London Special Publication, in Dilek, Y., \&.Robinson, P.T., eds, Ophiolites in Earth History (in press). 
Nicolas, A., 1986, A melt extraction model based on structural studies in mantle peridotites. Journal of Petrology, v. 27, pp. 999-1022.

Ottonello, G., Piccardo, G.B., and Joron, J.L., 1984, Rare Earth and 3rd transition element geochemistry of peridotitic rock. ii. Ligurian peridotites and associated basalts. J. Petrol., v. 25, pp. 379-393.

Piccardo, G.B., 1976, Petrologia del massiccio lherzolitico di Suvero (La Spezia). Ofioliti, v. 1, pp. 279-317.

Piccardo, G.B., 1977, Le ofioliti dell'areale ligure: petrologia ed ambiente geodinamico di formazione. Rend. Soc. It. Mineral. Petr., v. 33, pp. 221252.

Piccardo, G.B., 1983, Genesi delle ofioliti dellíAppennino Settentrionale. Mem. Soc. Geol. It., v. 25, pp. 75-89.

Piccardo, G.B., 1995, Ophiolites, in Ranalli, G., ed, Plate Tectonics: the First Twenty-five Years. Proceedings of the VIII Summer School Earth and Planetary Sciences, Tipografica Senese, pp. 267-296.

Piccardo, G.B., Rampone, E., and Vannucci., R., 1990, Upper mantle evolution during continental rifting and ocean formation: evidence from peridotite bodies of the Western Alpine-Northern Apennine system. Mem. Soc. Geol. France., v. 156, pp. 323-333.

Piccardo, G.B., Rampone, E. and Romairone, A., 2002, Formation and composition of the oceanic lithosphere of the Ligurian Tethys: inferences from the Ligurian ophiolites. Ofioliti, v. 27, pp. 145-161.

Rampone, E., 2002, Mantle dynamics during passive rifting vs. slow-spreading ocean formation. Swiss Geol Soc. - Swiss Soc. Min. Petr. SANW Annual Meeting, Workshop B- Birth and Early evolution of Alpine Ocean Basins, Abstract Volume, p. 38.

Rampone, E., Piccardo, G.B., Vannucci, R., Bottazzi, P., and Ottolini, L., 1993, Subsolidus reactions monitored by trace element partitioning: the spinel- to plagioclase-facies transition in mantle peridotites. Contrib. Mineral. Petrol., v. 115, pp. 1-17.

Rampone, E., Hofmann, A.W., Piccardo, G.B., Vannucci, R., Bottazzi, P., and Ottolini, L., 1995, Petrology, mineral and isotope geochemistry of the External Liguride Peridotites (Northern Apennine, Italy). J. Petrol., v. 36, pp. 81-105.

Rampone, E., Hofmann, A.W., Piccardo, G.B., Vannucci, R., Bottazzi, P., and Ottolini, L., 1996, Trace element and isotope geochemistry of depleted peridotites from an N-MORB type ophiolite (Internal Liguride, N. Italy). Contrib. Mineral. Petrol., v. 123, pp. 61-76.

Rampone, E., Piccardo, G.B., Vannucci, R. and Bottazzi, P., 1997, Chemistry and origin of trapped melts in ophiolitic peridotites. Geochim. Cosmochim. Acta, v. 61, pp. 4557-4569.

Rampone, E., Hofmann, A.W., and Raczek, I., 1998, Isotopic contrasts within the Internal Liguride ophiolite (N. Italy): the lack of a genetic mantlecrust link. Earth Planet. Sci. Lett., v. 163, pp. 175-189.

Rampone, E., and Piccardo, G.B., 2000, The ophiolite-oceanic lithosphere analogue: New insights from the Northern Apennine (Italy), in Dilek, J., Moores, E., Elthon, D. and Nicolas, A., eds, Ophiolites and Oceanic Crust: New Insights from Field Studies and Ocean Drilling Program: Boulder, Colorado, Geological Society Special Paper no. 349, pp. 21-34.
Serri, G., 1980, Chemistry and petrology of gabbroic complexes from the Northern Apennines ophiolites, in Panayiotou, A., ed, Ophiolites, Cyprus Geological Survey Department, Nicosia, pp. 296-313.

Schaltegger, U., Desmurs, L., Manatschal, G., Müntener, O., Meier, M., Frank, M., and Bernoulli, D., 2002, The transition from rifting to sea-floor spreading within a magma-poor rifted margin: field and isotopic constraints. Terra Nova, v. 14, pp. 156-162.

Stampfli, G.M., 1993, Le Brianconnais, terrain exotique dans les Alpes? Eclogae Geologicae Helvetiae, v. 86: pp. 1-45.

Tribuzio, R., Tiepolo, M., and Vannucci, R., 2000, Evolution of gabbroic rocks from the Northern Apennine ophiolites (Italy): Comparison with the lower oceanic crust from modern slow-spreading ridges. Geol. Soc. America, Special Paper v. 349, pp. 129-138.

Vannucci, R., Rampone, E., Piccardo, G.B., Ottolini, L., and Bottazzi, P., 1993, Ophiolitic magmatism in the Ligurian Tethys: An ion microprobe study of basaltic clinopyroxenes. Contrib. Mineral. Petrol., v. 115, pp. 123-137.

Vissers, R.L.M., Drury, M.R., Hoogerduijn Strating, E.H., and Van der Val, D., 1991, Shear zones in the upper mantle: a case study in an Alpine lherzoliti massif. Geology, v. 19, pp. 990-993.

Weissert, H.J., and Bernoulli, D., 1985, A transform margin in the Mesozoic Tethys: evidence from the Swiss Alps. Geologische Rundschau, v. 74, pp. 665-679.

Xu, Y-G., Menzies, M., Thirlwall, M.F., Huang X-L., Liu, Y., and Chen, XM., 2003, "Reactive" harzburgites from Huinan, NE China: Products of the lithosphere-asthenosphere interaction during lithospheric thinning? Geochim. Cosmochim. Acta., v. 67, pp. 487-505.

Giovanni B. Piccardo, Full Professor of Petrology at the University of Genova since 1980. Research activity in the fields of Petrology and Geochemistry of (1) Ophiolites from the Northern Apennine and the Western Alps; (2) Eclogites and HP metamorphic ophiolites from the Voltri Massif and the Western Alps; (3) Mantle Peridotites from oceanic and extensional settings (Red Sea, Northern Apennine and Lanzo) and mantle xenoliths in alkaline lavas (Eritrea).

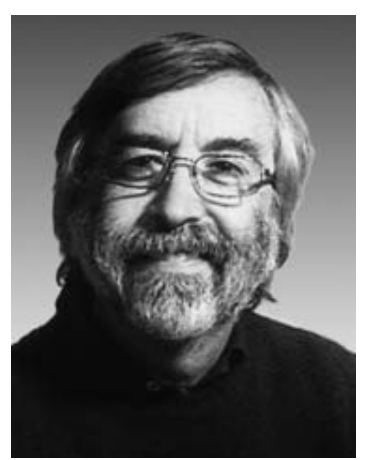

